\title{
A genetic study of infantile and juvenile myasthenia gravis
}

\author{
SARAH BUNDEY \\ From the MRC Clinical Genetics Unit, Institute of Child Health, London, \\ and the Institute of Neurology, Queen Square, London
}

SUMMARY From the present study, and from reports in the literature, two forms of childhood myasthenia emerge. There is an early-onset form (with onset of symptoms under 2 years of age) where the illness is milder but more persistent, and where there is frequent occurrence of myasthenia in sibs. Such cases are likely to be inherited as an autosomal recessive, although it is possible that they represent the extreme edge of a multifactorial distribution of combined genetic and environmental aetiology. The second group (with onset of symptoms between the age of 2 and 20 years) clinically resembles adult myasthenia, which is associated with autoimmunity and an increased incidence of thyroid dysfunction. Some genetic contribution occurs in this form but it is less marked than with the early-onset cases and there is no recognizable pattern of inheritance. As secondary cases are even less common among the families of adult myasthenics, it is likely that individuals with most genetic predisposition to myasthenia tend to develop symptoms early, and that non-genetic factors are relatively more important for the development of myasthenia in adults.

Myasthenia gravis has a prevalence of about 2-4 per 100,000 (Kurland and Alter, 1961; Hokkanen, 1969b), and is even less common in children. Cases with onset in infancy account for $1-2 \%$ of all cases (Millichap and Dodge, 1960);

1 Change of address and requests for reprints to S.B. at The Moore Clinic, Johns Hopkins Hospital, Baltimore, Maryland 21205, U.S.A. cases with onset under 10 years account for about $4.3 \%$ of all cases, and cases with onset under 20 years for about $24 \%$ of all cases. This age of onset distribution is shown in Table 1 , which also shows the nearly two-fold incidence of cases among females compared with males. Table 2 shows the earlier appearance of symp-

TABLE 1

DISTRIBUTION OF AGE OF ONSET OF SYMPTOMS OF MYASTHENIA GRAVIS WITHOUT THYMOMA

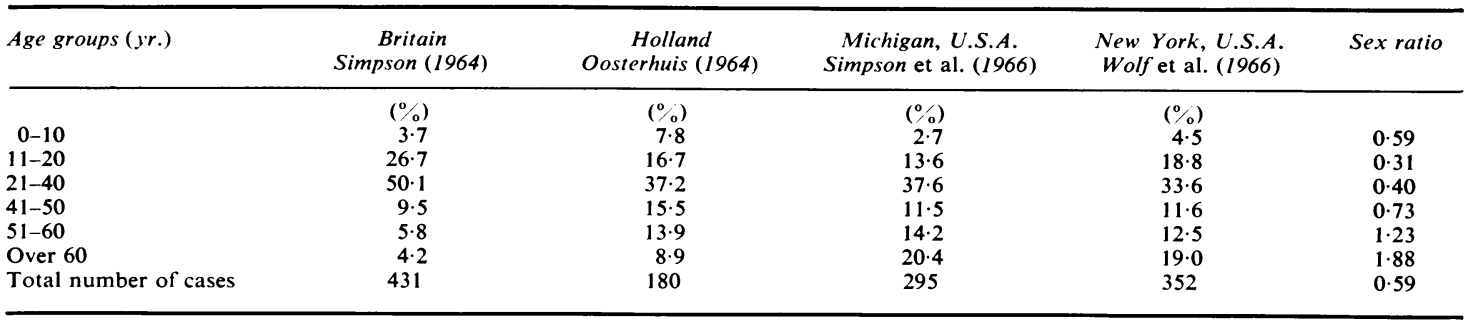

TABLE 2

CUMULATIVE DISTRIBUTION OF AGE OF ONSET OF SYMPTOMS OF MYASTHENIA GRAVIS*

\begin{tabular}{|c|c|c|c|c|c|c|c|}
\hline \multirow[t]{2}{*}{ Patients } & \multicolumn{7}{|c|}{ Percentage of myasthenic patients who developed symptoms } \\
\hline & By IO years & By 20 years & By 30 years & By 40 years & By 50 years & By 60 years & After 60 \\
\hline
\end{tabular}

* Data have been obtained from the four hospital surveys summarized in Table 1. 
toms in females with three-quarters of female myasthenics developing symptoms by 40 years. The incidence of myasthenia in males on the other hand rises more slowly from childhood, so

TABLE 3

FAMILIAL CASES OF MYASTHENIA GRAVIS*

\begin{tabular}{|c|c|c|c|}
\hline Reference & $\begin{array}{c}\text { Age of onset } \\
(y r .)\end{array}$ & $\begin{array}{c}\text { Affected } \\
\text { individuals }\end{array}$ & $\begin{array}{c}\text { Un- } \\
\text { affected } \\
\text { sibs (no.) }\end{array}$ \\
\hline
\end{tabular}

Sibs only affected: age of onset under 2 years:

\begin{tabular}{|c|c|c|}
\hline Rothbart (1937) & $<2$ & 4 Bro. \\
\hline Eaton (1947) & Infancy & 2 Bro. \\
\hline Levin (1949) & $<1$ & Bro. and $\mathrm{Si}$. \\
\hline \multicolumn{3}{|l|}{ Bornstein (1953) } \\
\hline $\begin{array}{l}\text { Kott and Bornstein } \\
\text { (1969) }\end{array}$ & $<3$ months & 3 Bro. $1 \mathrm{Si}$. \\
\hline Macrae (1954) & $<1$ & Bro. and $\mathrm{Si}$. \\
\hline $\begin{array}{l}\text { Biemond and } \\
\text { Trotsenburg (1955) }\end{array}$ & $15 / 12$ & $\begin{array}{l}\text { Dizygous } \\
\text { male twins }\end{array}$ \\
\hline $\begin{array}{l}\text { Teng and Osserman, } \\
1956\end{array}$ & Birth & Bro. and $\mathrm{Si}$. \\
\hline Walsh and Hoyt (1959) & $<2$ & 4 Bro. \\
\hline $\begin{array}{l}\text { Millichap and Dodge } \\
\text { (1960) }\end{array}$ & Birth + ? & Bro. and $\mathrm{Si}$. \\
\hline $\begin{array}{l}\text { Warot and Delahousse } \\
\text { (1964) }\end{array}$ & $<2$ & 2 Bro. \\
\hline Simpson (1964) & $<2$ & $2 \mathrm{Si}$ \\
\hline Herrmann (1966) & $1+3$ & Bro. and $\mathrm{Si}$. \\
\hline Fessard et al. (1968) & $6 / 12$ and $8 / 12$ & Si. and Bro. \\
\hline Gath et al. (1970) & Birth & Bro. and Si. \\
\hline Present study & $6 / 12$ and $18 / 12$ & 2 Bro. \\
\hline \multicolumn{3}{|c|}{ Sibs only affected: age of onset after 2 years: } \\
\hline Marinesco (1908) & $21+31$ & $2 \mathrm{Si}$. \\
\hline Hart (1927) & $9+14$ & $2 \mathrm{Si}$. \\
\hline $\begin{array}{l}\text { Riley and Frocht } \\
\text { (1943) }\end{array}$ & $11+14$ & $2 \mathrm{Si}$. \\
\hline Mancusi-Ungaro (1945) & $28+18$ & $2 \mathrm{Si}$. \\
\hline $\begin{array}{l}\text { Teng and Osserman } \\
(1956)\end{array}$ & $?$ & Bro. and $\mathrm{Si}$. \\
\hline $\begin{array}{l}\text { Goulon et al. (1960) } \\
\text { Greenberg (1964) }\end{array}$ & $\begin{array}{l}15+21 \\
19+40\end{array}$ & $\begin{array}{l}2 \mathrm{Si} . \\
2 \mathrm{Si} .\end{array}$ \\
\hline $\begin{array}{l}\text { Greenberg (1964) } \\
\text { Simpson (1964) }\end{array}$ & $42+?$ & $2 \mathrm{Si}$. \\
\hline Celesia (1965) & $/ 12+8$ & Si. and Bro. \\
\hline Herrmann (1966) & $33+36$ & 2 Bro. \\
\hline Namba and Grob (1971) & $29+39$ & $2 \mathrm{Si} . \dagger$ \\
\hline Present study & $18+24$ & $2 \mathrm{Si}$. \\
\hline
\end{tabular}

Other relatives affected:

\begin{tabular}{|c|c|c|}
\hline Noyes $(1930)$ & $?, 55+60$ & Fa. Son and Da. \\
\hline Bowman (1948) & $3+4$ & 1 st cousins ( $M$ and $F)$ \\
\hline Teng and Osserman & Childh ; 7 & 1st cousins ( $\mathrm{F}$ and ?) \\
\hline (1956) & $\begin{array}{l}\text { Birth; birth; } 1 \\
\quad ?+2\end{array}$ & $\begin{array}{l}\text { Bro. \& Si. 1st cousin (M) } \\
\text { Mo. and Son }\end{array}$ \\
\hline $\begin{array}{l}\text { Foldes and McNall } \\
\text { (1960) }\end{array}$ & $17 ; 39+27$ & Mo. + 2 Da. \\
\hline $\begin{array}{l}\text { Millichap and Dodge } \\
\text { (1960) }\end{array}$ & $?$ & $\begin{array}{l}\text { Female child and } 2 \\
\text { cousins }\end{array}$ \\
\hline Simpson (1964) & $21+27$ & cousins ( $M$ and $F)$ \\
\hline $\begin{array}{l}\text { Haralanov and } \\
\text { Kutchoukov (1966) }\end{array}$ & $46+18$ & Fa. and Da. \\
\hline Herrmann (1966) & $\begin{array}{c}26+8 \\
30 ' s+67 \\
55+71 \\
77+51\end{array}$ & $\begin{array}{l}\text { Fa. and Son } \\
\text { Sister and half-bros. Da. } \\
\text { 2nd cousins (M and F) } \\
\text { 1st cousins ( } 2 \mathrm{~F})\end{array}$ \\
\hline $\begin{array}{l}\text { Warrier and Pillai } \\
\quad(1967)\end{array}$ & $\begin{array}{l}16+12 \\
\text { Birth;2/12;3 }\end{array}$ & $\begin{array}{l}\text { Bro. and Si. } \\
\left\{\begin{array}{c}\text { nephews of above: } \\
\text { parents are cousins }\end{array}\right.\end{array}$ \\
\hline Present study & $10+4$ & Mo. and Son \\
\hline
\end{tabular}

* Monozygotic twins are not included in this Table, nor are familial cases reported by Oppenheim (1898) and Hokkanen (1969a) which are not fully documented.

t These four affected sisters also had hyperthyroidism. that it is not until the age of 60 that three quarters of male myasthenics will have developed symptoms.

Familial cases of myasthenia are rare, as shown by the survey of Jacob, Clack, and Emery (1968) where no secondary cases were found among 299 first degree relatives. Table lists familial cases from the literature, and two differences from the general pattern can be seen Firstly, there is a very young age distribution: 4 r. out of 97 familial cases $(42 \%)$ developing $\overrightarrow{\bar{s}}$ symptoms before the age of 2, and $64(66 \%$ before 20. Secondly, there is an excess of maleso among the familial cases with onset before $\overline{2}$. years of age ( 30 males to 11 females) but there i⿺ the expected excess of females after 2 years.

The clinical picture of myasthenia in infants and children has been described by Teng andOsserman (1956) and by Millichap and Dodgew (1960). These authors consider that the child $\frac{}{5}$ hood form commonly presents with ptosis anef ophthalmoplegia, although usually generalizedw muscular weakness develops later. The course of: the illness is more benign, but more persiste $\bar{b}, \stackrel{\rightarrow}{\rightarrow}$ than the adult form. Symptoms other the ophthalmoplegia, respond well to either mediga or surgical treatment, but a complete remission is expected in only about a quarter of cases. The infantile cases listed in Tables 3 and 4 suppere the above comments.

In view of the occurrence of familial cases myasthenia gravis among the younger age groups particularly, it was decided to carry outo a family study of myasthenics who developed symptoms in childhood. Twenty years was takeno as the upper age limit for onset of symptoms. It was hoped that such an unselected study would enable clearer elucidation of genetic factors ino음 myasthenia. It was also hoped to study the clinical features of any genetic entities that might appear, and to note the occurrence of auto immune disease in patients and their relatives. At the same time a study was made of the presence of autoantibodies and the levels of 3 . immunoglobulins in myasthenia gravis; thiso second study will be reported separately.

\section{METHOD}

The records of four London hospitals were consulted. Notes were obtained of patients who hado been diagnosed as having myasthenia gravis between $N$ 1942 and 1969; and who were aged under 25 when N the diagnosis was first coded, or who were otherwise 0 known to have had an early onset of symptoms 
TABLE 4

INFANTILE CASES OF MYASTHENIA GRAVIS*

$\begin{array}{lcc}\text { Author } & \begin{array}{c}\text { Sex of those } \\ \text { affected }\end{array} & \begin{array}{c}\text { No. of normal } \\ \text { sibs }\end{array}\end{array}$

Ramsay Hunt (1916)

Kawaichi and Ito (1942)

Yahr and Davis (1944)

Bowman (1948)

Wyllie et al. (1951)

Mackay (1951)

Walker (1953)

Macrae (1954)

Heinzen and Baasch (1955)

Teng and Osserman (1956)

Millichap and Dodge (1960)

Wiesendanger and Baasch (1962)

Oosterhuis (1964)

Wolf et al. (1966)

Present author (non-familial cases)

Familial cases from Table 3

$\begin{array}{cc}\mathrm{F} & 2 \\ \mathrm{M} & 0 \\ \mathrm{~F} & 2 \\ \mathrm{M} & 2 \\ \mathrm{~F} & 1 \\ \mathrm{~F} & 4 \\ \mathrm{~F} & ? \\ \mathrm{M} & 3 \\ \mathrm{M} & ? \\ 3 \mathrm{M} ; 5 \mathrm{~F} & ? \\ 3 \mathrm{M} ; 2 \mathrm{~F} & ? \\ 2 \mathrm{M} & ? \\ 1 \mathrm{M} ; 2 \mathrm{~F} & ? \\ 1 \mathrm{M} ; 1 \mathrm{~F} & ? \\ 1 \mathrm{M} ; 3 \mathrm{~F} & 7 \\ 27 \mathrm{M} ; 9 \mathrm{~F} & 11+\end{array}$

* Those with onset at 2 years or under; excluding transitory neonatal myasthenia.

From perusal of the records, patients were selected for inclusion in the study if their myasthenic symptoms developed before the 20th birthday, and if the patient lived within reach of London. The diagnosis of myasthenia was accepted if (1) the muscular weakness worsened after exercise or prolonged muscular contraction, or if it was otherwise variable in time; (2) if there was no evidence of myopathy (as shown by wasting or depressed reflexes) in the early stages; (3) and if the weakness responded to anticholinesterase drugs. Fluctuation of muscular weakness was always present, but one patient was excluded because of wasting of the shoulder girdle muscles when she was first seen; and another patient was excluded because his symptoms vanished before anticholinesterase drugs could be given.

Using the above criteria, a total of 66 patients were listed, but eight of these were not finally included as two refused to help and six could not be traced. Of the 58 index patients, 27 had attended the National Hospital, 17 had attended New End Hospital; 11 were from St. Bartholomew's Hospital; and 10 from The Hospital for Sick Children. Seven patients had attended two hospitals. Four index patients were not seen, as three had died and one was living abroad. However, information about these four patients was obtained from case notes and their families were included. Five index patients first developed symptoms of myasthenia under the age of 2 years (earlyonset cases) and 53 after this age (late-onset cases). In family 4 , the second brother, who is more severely affected, has been considered as the index patient, but it could be argued that his older brother, also affected, should be an index patient too, as they were referred to the National Hospital together.

The patients, or their parents, were visited at home and the living patients were assessed clinically. A family history was taken and questions asked about myasthenic symptoms or other illnesses in relatives. Where possible, all first degree relatives were seen, and briefly examined for evidence of myasthenia gravis, anaemia, thyroid dysfunction, arthropathy, or skin disorders. Where an earlier illness was reported by a patient or relative, and there was any doubt as to diagnosis, information was obtained from the records of general practitioners, or hospitals. If permission was granted, blood was taken from the patients and their first degree relatives for autoantibody and immunoglobulin studies.

One index patient was an adopted child, and so family details were not available. The remaining 57 families provided 253 first degree relatives of whom 18 came from the five families of early-onset cases and 235 from the families of late-onset cases. Thirtytwo relatives had died: of the 221 living relatives, 25 were not seen as 12 lived too far away, seven refused to help, and the whereabouts of a further six relatives were unknown. Thus, 196 relatives were seen (Table $5)$. Specimens of sera were obtained from 158 of these, those not subjected to venepuncture being mostly children. Autoantibodies and immunoglobulins were estimated on the sera. The results of these estimations will be the subject of a separate report (Bundey, Doniach, and Soothill, 1972).

TABLE 5

GENETIC SURVEY OF INFANTILE AND JUVENILE MYASTHENIA GRAVIS

\begin{tabular}{lccccc}
\hline & Total & Dead & $\begin{array}{c}\text { Alice and } \\
\text { not seen }\end{array}$ & Seen & $\begin{array}{c}\text { Antibodies } \\
\text { studied }\end{array}$ \\
\hline Index patients & $58^{*}(5)$ & 3 & 1 & $54(5)$ & $52(3)$ \\
Mothers & $57 \ddagger(5)$ & 9 & 2 & $46(5)$ & $45(4)$ \\
Fathers & $57^{\ddagger}(5)$ & 14 & $6(1)$ & $37(4)$ & $37(4)$ \\
Sisters $\dagger$ & $45(1)$ & 2 & 8 & $35(1)$ & 32 \\
Brothers $\dagger$ & $50(7)$ & $5(1)$ & $7(2)$ & $38(4)$ & $33(2)$ \\
Half-sisters $\dagger$ & 2 & 1 & 0 & 1 & 0 \\
Half-brothers $\dagger$ & 7 & 1 & 0 & 6 & 3 \\
Children $\dagger$ & 35 & 0 & 2 & 33 & 8 \\
\hline
\end{tabular}

* Unenclosed figures refer to total; figures in brackets to early-onset patients and their relatives.

+ Figures refer to liveborn relatives.

$\ddagger$ One index patient was adopted.

\section{RESULTS}

EARLY-ONSET CASES AND THEIR RELATIVES Clinical details of the patients who developed symptoms before the age of 2 (cases 1-5) are summarized in Appendix 1. All presented initially with ptosis; in three cases $(2,4$, and 5$)$ this was the only symptom for some time, the diagnosis of myasthenia being delayed for six months in cases 4 and 5 and seven years in case 2 . Ophthalmoplegia was detected in all cases when the child presented for medical attention. In cases 1 and 3, facial and bulbar weakness were also present initially; case 3 was diagnosed four 
months after onset, but case 1 was not diagnosed until the age of 25 years, shortly after she came to Great Britain from India. Cases 1 and 2 illustrate the very slow course of the illness in early-onset myasthenia; and cases 3 and 5 have shown no progression while under observation, for two and seven years respectively. None of the early-onset cases has developed myopathic features. The present state of four of the patients is good; but case 1, who has had myasthenia for 31 years, is moderately disabled though still at full-time work. None of these early-onset cases has had a thymectomy.

There is one secondary case among these families: the elder brother of case 4 who at 6 months of age developed ptosis, together with some difficulty in feeding and swallowing. There has been no progression of his symptoms during eight years' observation. There are no other sibs in this family; there are seven unaffected sibs in the other four families.

In two families (1 and 5) the parents are first cousins. Family 1 is a Jewish family from India, and first cousin marriage is not usual in this group; family 5 is English. Further genetic data about these families of early-onset cases are given in Appendix 2.

There was no suggestion of an increase of thyroid dysfunction nor of autoimmune disease among four of these families; but in family 1 the mother has rheumatoid arthritis and the father has pernicious anaemia. The eldest brother died in India at the age of 31 years of an unknown disease associated with chronic anaemia.

LATE-ONSET CASES There were 43 females and 10 응 males who developed symptoms in childhood or adolescence, and their present ages range from 9 to 46 years (Figure). Clinical information is summarized in Appendix 1. The mode of onset of symptoms included ptosis with or without ophthalmoplegia in 20 patients, but in only: three cases, all with onset under 8 years of age, $\stackrel{\rho}{=}$ did muscular weakness remain confined to the $\overline{0}$ eyes. Only two patients (cases 14 and 48) never 흠 had involvement of eye muscles during the $\frac{\bar{\omega}}{\vec{D}}$ course of their illness. In 18 patients weakness of $\stackrel{\mathbb{D}}{\Omega}$ limbs was a presenting complaint. In six cases onset of myasthenic symptoms immediately fol- $\overrightarrow{0}$ lowed infection or allergy. In cases 8 and $9, \overrightarrow{\vec{H}}$ ptosis developed while the rash of varicella was still present, and was later followed by other symptoms of myasthenia. Case 57 developed ptosis and bulbar weakness while convalescing from infectious mononucleosis. Case 31 de veloped dysarthria towards the end of an attack $\underline{\vec{B}}$ of acute nephritis which lasted two month@ 을 Case 55 developed double vision shortly after $\vec{P}$ course of desensitizing injections for hay feve $\mathbb{Q}$ and case 21 developed facial and bulbar weakg ness two months after an attack of urticaria an angioneurotic oedema.

The course of the illness in the early stage before treatment was usually slowly progressive

Ages of Onset of Symptoms in 58 Index Patients

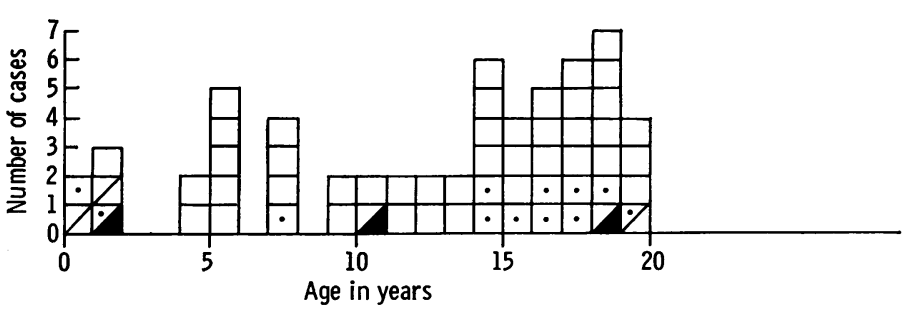

Present Ages, or Ages at Death, of Index Patients

Females

- Males

Cases with consanguineous parents

Cases with an affected relative

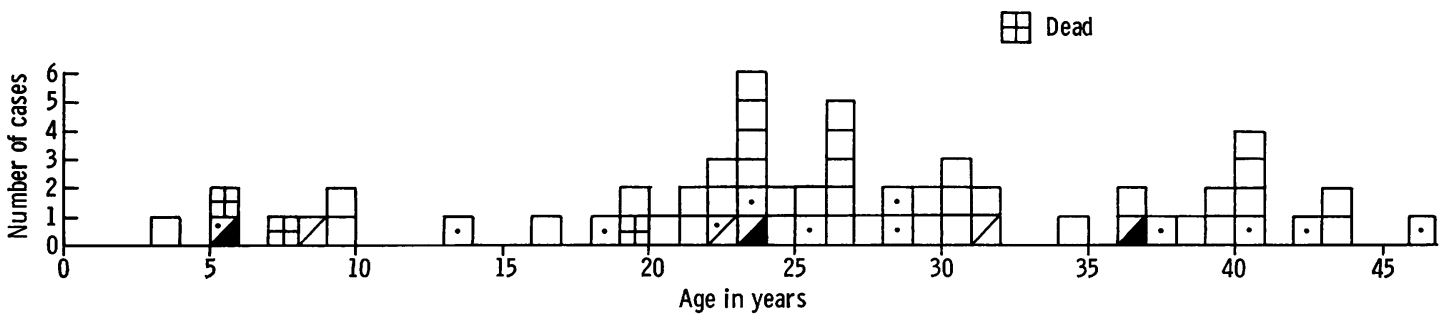

FIGURE Juvenile myasthenia gravis. 
with relapses and remissions of up to a few months. There were eight patients in whom initial progression of symptoms was rapid and severe, and four of these have done badly; one died, and three are now moderately or severely affected.

Forty-five patients ( 36 females and nine males) had had a thymectomy. However, the effect of thymectomy could not be assessed retrospectively, as the indications for operation were not always clear, nor were they consistent. Thymic pathology was reported in 27 patients and, of these, 22 showed the lymphoid hyperplasia characteristic of myasthenia gravis.

The present clinical status of living patients was assessed by symptoms and by whether they were having treatment. Gradings of present severity of illness are given in Appendix 1 . Nineteen patients $(38 \%)$ are off drugs; 11 patients have no symptoms although they are still on drugs; eight patients on drugs have mild symptoms only; a further nine patients have moderately severe symptoms but are able to continue at work; and three patients lead very severely restricted lives. There was no clinical evidence of neurological disorder other than that of the myasthenia. The distribution of intelligence in the patients was normal, and no patient was mentally retarded. No patient had focal muscle wasting or depressed reflexes. Two of the severely affected patients (cases 19 and 33) had some generalized wasting of muscle, but reflexes were preserved.

Thyroid disorder was noticeably common among index patients. Three patients (cases 12, 49, and 50) had overt thyroid disease. Case 12 developed symptoms of thyrotoxicosis 19 years after her myasthenia began, and two years after thymectomy. Limb and bulbar weakness worsened with the thyrotoxicosis, and improved when the latter was treated firstly by carbimazole, and then by radioactive iodine. She is now euthyroid, and needs no anticholinesterase treatment. She has, however, an insulin dependent diabetes which developed in the postoperative period. Case 49 developed primary myxoedema at the age of 17 years. She responded well to thyroxine; seven months later she developed symptoms of myasthenia gravis. Case 50 presented with a goitre at the age of 18 years. Three months later she developed ptosis and other symptoms of myasthenia; three months after this, she became overtly thyrotoxic and has since been on carbimazole and pyridostigmine. Two further patients (cases 17 and 54) are clinically euthyroid but have goitres; and case 32 , has hypothyroidism as shown by $\mathrm{T}_{3}$ uptake, and PBI level.

Other illnesses in patients include rheumatoid arthritis with a negative latex test (case 29), previous rheumatic fever (case 33), and previous acute nephritis (case 31 and 36).

RELATIVES OF LATE-ONSET CASES The age distribution of first-degree relatives of late-onset cases is shown in Table 6. If it is assumed that such relatives, should they develop myasthenia, are likely to do so at similar times to the myasthenic patients in the four large surveys described in Tables 1 and 2, then the risk periods passed, for the two sexes separately, are shown in the right-hand column of Table 6 . Considering all relatives together, they have passed, by the time of the study, about $58 \%$ of the risk period for developing symptoms of myasthenia gravis.

There are in fact two secondary cases of myasthenia among the families of juvenile cases. The son and only child of case 20 developed dysarthria at about 4 years of age; later weakness of face and limbs appeared. He is on medical

TABLE 6

AGE DISTRIBUTION* OF FIRST-DEGREE RELATIVES OF LATE-ONSET CASES OF MYASTHENIA GRAVIS AND AN ESTIMATE OF THE RISK PERIOD FOR DEVELOPING MYASTHENIA WHICH HAS BEEN PASSED

\begin{tabular}{|c|c|c|c|c|c|c|c|c|}
\hline & \multicolumn{7}{|c|}{ Years } & \multirow{2}{*}{$\begin{array}{c}\text { Total risk } \\
\text { period passed } \dagger \\
(\%)\end{array}$} \\
\hline & $0-10$ & $11-20$ & $21-30$ & $31-40$ & $4 I-50$ & $51-60$ & Over 60 & \\
\hline Mothers (52) & & & 1 & 4 & 9 & 19 & 19 & 92 \\
\hline Fathers $(52)$ & & & 2 & 2 & 7 & 18 & 23 & 82 \\
\hline Sisters and half-sisters (46) & 5 & 5 & 16 & 13 & 4 & 3 & $\mathbf{0}$ & 58 \\
\hline Brothers and half-brothers $(50)$ & 11 & 6 & 13 & 13 & 5 & 2 & 0 & 33 \\
\hline Children (35) & 25 & 10 & & & & & & 10 \\
\hline
\end{tabular}

* Present age if alive, or age at death.

+ This risk period for developing symptoms of myasthenia has been calculated by comparing the age distribution of relatives with the risk period passed for different ages as shown in Table 2. 
treatment. The sister of case 51 developed double vision and other symptoms of myasthenia at the age of 24 years. A neuromuscular transmission defect was shown on electromyography, and she improved with edrophonium and then oral anticholinesterase drugs. There is one healthy brother in this family.

There is one instance of consanguinity among the 52 families studied: the parents of case 55 are second cousins. There are three other healthy sibs in this family. There is one pair of monozygous twins, now aged 20, where the index patient (no. 41) only is affected. There is one pair of discordant unlike-sex dizygous twins (no. 45), aged 40.

Twenty index patients have had children, and of these parents, 10 were off treatment at the time of their pregnancies. Three out of 15 children born to parents on treatment had transitory neonatal myasthenia; while none of the 20 children born to parents off drugs had neonatal myasthenia.

It was considered that information about other illnesses was reliable on all 235 first degree relatives, although only 182 were seen personally. An abnormality of the thyroid gland was present in 14 first degree relatives $(6.0 \%)$. This abnormality consisted of thyrotoxicosis in four parents, and simple goitre in 10 further relatives, the thyroid enlargement being sufficient in seven instances to lead the relative to seek medical advice; one had had a partial thyroidectomy and six others had been investigated at hospital for evidence of thyroid dysfunction. In three instances the goitre was not a complaint of the relative but was detected at the time of examination.

Other illnesses in relatives include rheumatic fever (four parents and two brothers), rheumatoid arthritis (one father), Raynaud's disease (one mother), and one brother had a fatal illness resembling polyarteritis nodosa, but without pathological confirmation. One or more of the allergic diseases (eczema, hay fever, asthma, and drug sensitivity) were present in $17 \%$ of first degree relatives, an incidence which is probably not increased beyond that found in the general population (Van Arsdel and Motulsky, 1959).

\section{DISCUSSION}

CASES WITH ONSET UNDER AGE OF 2 YEARS Familial cases of myasthenia gravis from the literature are shown in Table 3. The first group is composed of cases presenting in infancy or $z$ soon after; the upper age limit has been taken as $\stackrel{\mathbb{D}}{\subseteq}$ 2 years, although this is not definitive, and there is an affected sister in the Table, with onset of symptoms at 3 years. These families are not 0 suitable for segregation analysis as they are selected for being of particular genetic interest and have been reported when at least two sibs are affected. There are no reported instances of consanguinity but otherwise the data, with sibs only affected, suggests autosomal recessive inheritance. There is, however, a male excess (26 males to 10 females) which is difficult to explain, as it is not reflected in the sporadic infantile cases (Table 4 shows 15 males to 18 females) nor क by the familial cases with later age of onset (the $\vec{\circ}$ second group in Table 3 shows 20 sisters and four brothers affected). The male excess in the familial infantile cases might suggest a rare $X$ linked form of myasthenia gravis, but there are no families reported with both sons and maternal $\dot{c}_{\pi}$ uncles affected to give support to this view. It is $-\overrightarrow{-}$ more probable that the male excess has arisen bs chance.

The results of the present study are in keepin 8 with the suggestion that there is an autosoma $\frac{\Phi}{\mathbb{D}}$ T recessive early-onset form of myasthenia graviso There are five families in the series where the index patient developed symptoms at two years. or under, and among these five families there are two where the parents are first cousins, and one family with two brothers affected. There are seven unaffected sibs in these families: one sib affected out of eight is consistent with a 1 in 4 risk. If the brother of case 4 is also counted as an index patient, then the numbers of affected sibs are two out of nine. The clinical picture in the six affected differs in course from other forms of myasthenia. As in the cases described by Millichap and Dodge (1960) the illness is mild, static, or only slowly progressive, but more persistent than the adult form.

The suggested upper age limit of 2 years for the early-onset form may not be definitive. Cases 7 and 8 in this series clinically resemble the five younger cases, apart from age of onset, but in these families there are four further unaffected sibs. Similarly, there are likely to be cases with onset under 2 years which fall into the late-onset group.

Although recessive inheritance is the most likely explanation for the findings in this small group of families, other more complicated 
explanations are possible. For example, the families could be at the extreme end of a distribution curve for polygenic inheritance, and so show a high aggregation of cases within families. There are insufficient data to consider this point further.

CASES WITH ONSET IN CHILDHOOD AND ADOLESCENCE The familial cases in the older age groups, listed in Table 3, have a similar sex distribution to that seen in general surveys of myasthenia gravis, with 38 females and 20 males affected. However, the age distribution is significantly altered, with only $25(41 \%$ of the older familial cases) developing symptoms after the age of 20 , against a usual figure of $76 \%$ (Table 1).

In the present survey, among the families of older index patients, there are two secondary cases (a sister and a son) and one family where the parents are second cousins. These facts strongly suggest some genetic contribution to juvenile myasthenia gravis. Further support for a genetic component is that three concordant monozygotic twins have been reported, aged 4 to 23 (Adler, 1966; Osborne and Simcock, 1966; Herman, 1969). The ages of onset of symptoms in the twin pairs varied by only two to three years. Unfortunately, there is no unselected twin study. There are six instances of discordant monozygotic twins, one from the present study, and five from the literature, aged 4 to 40 years (Wilson and Stoner, 1944; Alter and Talbert, 1960; Simpson, 1965; Haralanov and Kutchoukov, 1966; Motoki, Harada, Chiba, and Honda, 1966).

Although some genetic contribution is likely for juvenile myasthenia gravis, there is no certain genetic mechanism. It is unlikely that either dominant or recessive genes are important as the risk to sibs is similar to the risk to children. Table 3 shows more sibs than children affected, but no information is given on the number of children at risk. Table 3 also shows several second and third degree relatives affected, which makes recessive inheritance unlikely; and second and third degree relatives affected without an intervening affected first degree relative, making dominant inheritance unlikely. The occurrence of myasthenia in second and third degree relatives also makes it unlikely that a shared environment accounts for the increased familial incidence. It is impossible, on the small figures available, to test for polygenic inheritance.
The prevalence of myasthenia in first degree relatives of patients presenting in childhood or adolescence in this series is two out of 235 or about $1 \%$. If it is correct to assume that these relatives have passed only $58 \%$ of the risk period for developing symptoms of myasthenia gravis, then the expected incidence of myasthenia in first degree relatives would be nearly doubled. However, it may be incorrect to make such allowances, for it is reasonable to suppose that relatives of index patients selected for an early onset of symptoms, are likely themselves to develop myasthenia early.

The prevalence of myasthenia in relatives of adult index patients is less than this (Jacob et al., 1968) and familial adult cases are rarely reported in the literature. This would suggest that those who are most genetically prone to develop myasthenia tend to do so in early life, and those less genetically prone, tend to do so later.

The clinical picture of the myasthenia in patients presenting in childhood and adolescence in this series is similar to that seen in adults. Also, the incidence of hyper- or hypothyroidism in patients $(5.5 \%)$ is similar to the increased incidence in adults with myasthenia gravis reported by other authors (Millikan and Haines, 1953; Simpson, 1960, 1968; Drachman, 1962; Osserman, Tsairis, and Weiner, 1967; Hokkanen, 1969a). The incidence in this study is certainly higher than that in the general population, particularly when one considers the young age of the patients. Presumably, the same factors that predispose an individual to develop myasthenia gravis, also predispose him or her to develop thyroid disease, a suggestion that was first made by Simpson (1960). Thyroid dysfunction is also unduly common in first-degree relatives in this study. Ten relatives out of $235(4.2 \%)$ had a goitre, but this incidence is not certainly increased above that found in the general population (Kilpatrick, Milne, Rushbrooke, Wilson, and Wilson, 1963; Dingle, Ferguson, Horn, Tubmen, and Hall, 1966). However, the incidence of four relatives $(1.7 \%)$ with proven thyrotoxicosis is high. Kilpatrick et al. (1963) found an incidence of proven thyrotoxicosis (past or present) of $0.07 \%$ for a general practice in Scotland. It was interesting that these workers found a significantly higher incidence $(0.75 \%)$ in a suburb of Sheffield, where the prevalence of goitre was $21 \%$. However, in the present survey, centred on south-east England, there was no reason to make a comparison with a highly 
goitrous area. This increased incidence of thyrotoxicosis in relatives supports Simpson's suggestion (1968) that some of the factors predisposing patients with myasthenia gravis to thyroid dysfunction are genetic.

There is now good evidence for considering adult myasthenia gravis as an autoimmune disease. Such evidence includes the presence of lymphoid hyperplasia in the thymus; the frequent clinical improvement that follows thymectomy; the association, in adults, of myasthenia with other autoimmune disorders (Simpson, 1960; Downes, Greenwood, and Wray, 1966); the increased incidence of muscle antibodies in adult patients (Strauss, Seegal, Hsu, Burkholder, Nastuk, and Osserman, 1960; Van der Geld, Feltkamp, Van Loghem, Oosterhuis, and Biemond, 1963; Adner, Sherman, Isé, Schwab, and Dameshek, 1964); and more recent experimental evidence (Goldstein and Whittingham, 1966; Goldstein, 1968). The present clinical study does not show a definite increase in autoimmune disease in patients, but this may be related to their relatively young age. Probably superimposed on an autoimmune background for myasthenia are hormonal influences, for these would account for the frequent appearance of symptoms in women of child-bearing age, and a later and less frequent appearance of myasthenia in men.

I should like to thank Mr. M. J. Lange of New End Hospital, and the consultants of The National Hospital, Queen Square, The Hospital for Sick Children, and St. Bartholomew's Hospital, for allowing me to study patients under their care. I am grateful to Dr. C. O. Carter, Professor R. W. Gilliatt, and Dr. J. Wilson for advice in the preparation of this manuscript. I am indebted to Dr. R. T. C. Pratt for suggesting the survey.

\section{REFERENCES}

Adler, E. (1966). Myasthenia gravis bei eineiigen Zwillingen. Deutsche medizinische Wochenschrift, 91, 396-397.

Adner, M. M., Sherman, J. D., Isé, C., Schwab, R. S. and Dameshek, W. (1964). An immunologic survey of fortyeight patients with myasthenia gravis. New England Journal of Medicine, 271, 1327-1333.

Alter, M., and Talbert, O. R. (1960). Myasthenia gravis in one monozygotic twin. Neurology (Minneap.), 10, 793-798.

Arsdel, P. P. van, Jr., and Motulsky, A. G. (1959). Frequency and hereditability of asthma and allergic rhinitis in college students. Acta Genetica et Statistica Medica, 9, 101-114.

Biemond, A., and Trotsenburg, L. van (1955). Over congenitale en infantiele myasthenie. Maandschrift voor kindergeneeskunde, 23, 155-164.

Bornstein, B. (1953). Familial early infantile myasthenia gravis. Acta Paediatrica, 42, 442-447.

Bowman, J. R. (1948). Myasthenia gravis in young children. Pediatrics, 1, 472-477.
Bundey, S., Doniach, D., and Soothill, J. F. (1972). (In preparation.)

Celesia, G. G. (1965). Myasthenia gravis in two siblings. Archives of Neurology, 12, 206-210.

Dingle, P. R., Ferguson, A., Horn, D. B., Tubmen, J., and Hall, R. (1966). The incidence of thyroglobulin antibodies and thyroid enlargement in a general practice in north-east England. Clinical and Experimental Immunology, 1, 277284.

Downes, J. M., Greenwood, B. M., and Wray, S. H. (1966). Auto-immune aspects of myasthenia gravis. Quarterly Journal of Medicine, 35, 85-105.

Drachman, D. B. (1962). Myasthenia gravis and the thyroid gland. New England Journal of Medicine, 266, 330-333.

Eaton, L. M. (1947). Personal communication to Levin (1949).

Fessard, C., Frezal, J., Roy, C., Martinez, F., Bardier, A., and Lamy, M. (1968). Une observation familiale de myasthénie de la première enfance. Archives Françaises de Pédiatrie, 25, 291-299.

Foldes, F. F., and McNall, P. G. (1960). Unusual familial occurrence of myasthenia gravis. Journal of the American Medical Association, 174, 418-420.

Gath, I., Kayan, A., Leegaard, J., and Sjaastad, O. (1970). Myasthenia congenita: electromyographic findings. Acta Neurologicae Scandinavica, 46, 323-330.

Geld, H. van der, Feltkamp, T. E. W., Loghem, J. J. van, Oosterhuis, H. J. G. H., and Biemond, A. (1963). Multiple antibody production in myasthenia gravis. Lancet, 2, 373375.

Goldstein, G. (1968). The thymus and neuromuscular funct tion. Lancet, 2, 119-122.

Goldstein, G., and Whittingham, S. (1966). Experimenta autoimmune thymitis. Lancet, 2, 315-318.

Goulon, M., Tournilhac, M., Lorin, M. C., and Nouailhaf T Fr. (1960). Myasthénie familiale. Revue Neurologique, 103 109-117.

Greenberg, J. (1964). Myasthenia gravis and hyperthyroidisfe्f in two sisters. Archives of Neurology, 11, 219-222.

Haralanov, H., and Kutchoukov, M. (1966). Myasthéniẹ familiale (père et fille) avec hyperplasie du thymus. Revu Neurologique, 114, 437-442.

Hart, H. H. (1927). Myasthenia gravis with ophthalmoplegia and constitutional anomalies in sisters. Archives of Neurology and Psychiatry, 18, 439-442.

Heinzen, H., and Baasch, E. (1955). Ophthalmoplegie bei kongenitaler Myasthenia gravis. Ophthalmologica, 129, 335-341.

Herman, M. N. (1969). Familial myasthenia gravis. Archives of Neurology, 20, 140-146.

Herrmann, C., Jr. (1966). Myasthenia gravis occurring in families. Neurology (Minneap.), 16, 75-85.

Hokkanen, E. (1969a). Myasthenia gravis. A clinical analysis of the total material from Finland. Annals of Clinical Research, 1, 94-108.

Hokkanen, E. (1969b). Epidemiology of myasthenia gravis in Finland. Journal of Neurological Sciences, 9, 463-478.

Hunt, J. R. (1916). Myasthenia gravis in a child of eight years. Boston Medical and Surgical Journal, 175, 169.

Jacob, A., Clack, E. R., and Emery, A. E. H. (1968). Genetic study of sample of 70 patients with myasthenia gravis. Journal of Medical Genetics, 5, 257-261.

Kawaichi, G. K., and Ito, P. K. (1942). Myasthenia gravis. Report of its occurrence in a twenty-one month old infant. American Journal of Diseases in Childhood, 63, 354-356.

Kilpatrick, R., Milne, J. S., Rushbrooke, M., Wilson, N E. S. B., and Wilson, G. M. (1963). A survey of thyroid enlargement in two general practices in Great Britain. British Medical Journal, 1, 29-34.

Kott, E., and Bornstein, B. (1969). Familial early infantile myasthenia gravis with a 15-year follow-up. Journal of Neurological Sciences, 8, 573-578. 
Kurland, L. T., and Alter, M. (1961). Current status of the epidemiology and genetics of myasthenia gravis, pp. 307336. In Myasthenia Gravis. Edited by $\mathbf{H}$. R. Viets. The second international symposium proceedings. Thomas: Springfield, Ill.

Levin, P. M. (1949). Congenital myasthenia in siblings. Archives of Neurology, 62, 745-758.

Mackay, R. I. (1951). Congenital myasthenia gravis. Archives of Diseases in Childhood, 26, 289-293.

Macrae, D. (1954). Myasthenia gravis in early childhood. Pediatrics, 13, 511-520.

Mancusi-Ungaro, L. (1945). Familial myasthenia gravis. Annals of Internal Medicine, 23, 249-251.

Marinesco, G. (1908). Contribution à l'étude de la myasthénie grave pseudo-paralytique. La Sémaine Médicale, 28, 421429.

Millichap, J. G., and Dodge, P. R. (1960). Diagnosis and treatment of myasthenia gravis in infancy, childhood, and adolescence. Neurology (Minneap.), 10, 1007-1014.

Millikan, C. H., and Haines, S. F. (1953). The thyroid gland in relation to neuromuscular disease. Archives of Internal Medicine, 92, 5-39.

Motoki, R., Harada, M., Chiba, A., and Honda, K. (1966). A case of myasthenia gravis of indentical twin brothers. International Surgery, 45, 674-677.

Namba, T., and Grob, D. (1971). Myasthenia gravis and hyperthyroidism occurring in two sisters. Neurology (Minneap.), 21, 377-382.

Noyes, A. P. (1930). A case of myasthenia gravis with certain unusual features. Rhode Island Medical Journal, 13, 52-59.

Oosterhuis, H. J. G. H. (1964). Studies in myasthenia gravis. Part I. A clinical study of 180 patients. Journal of Neurological Sciences, 1, 512-546.

Oppenheim, H. (1898). Lehrbuch der Nervenkrankheiten für Aerzte und Studirende, 2nd edn, p. 716. Karger: Berlin.

Osborne, D., and Simcock, J. (1966). Myasthenia gravis in identical twins. British Medical Journal, 1, 1025-1026.

Osserman, K. E., Tsairis, P., and Weiner, L. B. (1967). Myasthenia gravis and thyroid disease: clinical and immunological correlation. Journal of the Mount Sinai Hospital, 34, 469-483.

Riley, H. A., and Frocht, M. (1943). Myasthenia gravis. Familial occurrence. Archives of Neurology, 49, 904-908.

Rothbart, H. B. (1937). Myasthenia gravis in children. Its familial incidence. Journal of the American Medical Association, 108, 715-717.

Simpson, J. A. (1960). Myasthenia gravis: a new hypothesis. Scottish Medical Journal, 5, 419-436.
Simpson, J. A. (1964). Myasthenia Gravis. Thesis presented for degree of M.D. University of Glasgow.

Simpson, J. A. (1965). Myasthenia gravis. In Biochemical Aspects of Neurological Disorders, 2nd series, pp. 53-72. Edited by J. N. Cumings and M. Kremer. Blackwell: Oxford.

Simpson, J. A. (1968). The correlations between myasthenia gravis and disorders of the thyroid gland. In Research in Muscular Dystrophy, pp. 31-41. Pitman Medical: London.

Simpson, J. F., Westerberg, M. R., and Magee, K. R. (1966). Myasthenia gravis. Acta Neurologica Scandinavica, 42, Suppl. 23.

Strauss, A. J. L., Seegal, B. C., Hsu, K. C., Burkholder, P. M., Nastuk, W. L., and Osserman, K. E. (1960). Immunofluorescence demonstration of a muscle binding, complement-fixing serum globulin fraction in myasthenia gravis. Proceedings of the Society for Experimental Biology and Medicine, 105, 184-191.

Teng, P., and Osserman, K. E. (1956). Studies in myasthenia gravis: neonatal and juvenile types. Journal of the Mount Sinai Hospital, 23, 711-727.

Walker, R. P. (1953). Congenital myasthenia gravis. American Journal of Diseases in Childhood, 86, 198-200.

*Walsh, F. B., and Hoyt, W. F. (1959). External ophthalmoplegia as part of congenital myasthenia in siblings. American Journal of Ophthalmology, 47, $+28-34$.

Warot, P., and Delahousse, J. (1964). Myasthénie infantile chez deux frères. Lille Médical, 9, 690-695.

Warrier, C. B. C., and Pillai, T. D. G. (1967). Familial myasthenia gravis. British Medical Journal, 3, 839-840.

Wiesendanger, M., and Baasch, E. (1962). Myasthenia gravis im Kindesalter. Deutsche Zeitschrift für Nervenheilkunde, 184, 23-43.

Wilson, A., and Stoner, H. B. (1944). Myasthenia gravis: a consideration of its causation in a study of fourteen cases. Quarterly Journal of Medicine, 13, 1-18.

Wolf, S. M., Rowland, L. P., Schotland, D. L., McKinney, A. S., Hoefer, P. F. A., and Aranow, H., Jr. (1966). Myasthenia as an autoimmune disease: clinical aspects. Annals of the New York Academy of Science, 135, 517-535.

Wyllie, W. G., Bodian, M., and Burrows, N. F. E. (1951). Myasthenia gravis in children. Archives of Diseases in Childhood, 26, 457-466.

Yahr, M. D., and Davis, T. K. (1944). Myasthenia gravisits occurrence in a seven-year-old female child. Journal of Pediatrics, 25, 218-225.

* This is a special number, with separate pagination. It is indicated by a dagger preceding the pagination.

\begin{tabular}{|c|c|c|c|c|c|c|c|c|c|c|c|c|c|c|}
\hline \multirow[t]{2}{*}{$\begin{array}{l}\text { Hospital } \\
\text { no.* }\end{array}$} & \multirow[t]{2}{*}{$\begin{array}{l}\text { Surcey } \\
\text { no. }\end{array}$} & \multirow[t]{2}{*}{ Sex } & \multirow{2}{*}{$\begin{array}{c}\text { Year } \\
\text { of } \\
\text { birth }\end{array}$} & \multirow{2}{*}{$\begin{array}{c}\text { Age } \\
\text { of } \\
\text { onset } \\
(y r .) \\
\end{array}$} & \multirow[t]{2}{*}{$\begin{array}{c}\text { Mode of } \\
\text { onset }\end{array}$} & \multirow{2}{*}{$\begin{array}{l}\text { Initial } \\
\text { course } \\
\text { of ill- } \\
\text { nesst }\end{array}$} & \multicolumn{4}{|c|}{$\begin{array}{c}\text { Distribution of } \\
\text { muscle weakness } \ddagger\end{array}$} & \multirow{2}{*}{$\begin{array}{c}\text { Age at } \\
\text { thymec- } \\
\text { tomy } \\
(y r .)\end{array}$} & \multirow{2}{*}{$\begin{array}{c}\text { Age when } \\
\text { seen }(\text { or } \\
\text { at death) } \\
(y r .)\end{array}$} & \multirow{2}{*}{$\begin{array}{c}\text { Present } \\
\text { disability } \$\end{array}$} & \multirow[t]{2}{*}{$\begin{array}{c}\text { Other } \\
\text { illnesses }\end{array}$} \\
\hline & & & & & & & Eyes & Bulbar & $U L$ & $L L$ & & & & \\
\hline \multicolumn{15}{|c|}{ Onset under 2 years: } \\
\hline $\mathrm{A} 14892(\mathrm{~N})$ & 1 & $F$ & 1938 & $6 / 12$ & $\begin{array}{l}\text { Ptosis. Feeding } \\
\text { difficulty }\end{array}$ & SP & + & + & + & + & - & 31 & IV & \\
\hline 407693 (C) & 2 & $\mathbf{M}$ & 1956 & $6 / 12$ & Ptosis & $\mathrm{S}$ & + & + & + & + & - & 13 & III & \\
\hline 391249 (C) & 3 & $\mathrm{~F}$ & 1966 & $15 / 12$ & Ptosis & $\mathbf{S}$ & + & + & - & - & - & 3 & II & $\begin{array}{l}\text { Congenital } \\
\text { rubella }\end{array}$ \\
\hline $\left.\begin{array}{l}\text { A33941 (N) } \\
412967(\mathrm{C})\end{array}\right\}$ & 4 & $\mathbf{M}$ & 1964 & $18 / 12$ & Ptosis & SP & + & + & + & + & - & 5 & III & \\
\hline $335874(\mathrm{C})$ & 5 & $\mathbf{F}$ & 1960 & $18 / 12$ & Ptosis & $\mathbf{S}$ & + & - & - & - & - & 8 & II & \\
\hline \multicolumn{15}{|c|}{ Onset over 2 years: } \\
\hline $382365(\mathrm{C})$ & 6 & $\mathbf{F}$ & 1960 & 4 & $\begin{array}{l}\text { Ptosis. } \\
\text { Diplopia }\end{array}$ & RP & + & + & + & + & 5 & d. at 5 & - & \\
\hline $413992(\mathrm{C})$ & 7 & $\mathrm{~F}$ & 1960 & 4 & Ptosis & $\mathrm{S}$ & + & - & - & - & - & 9 & II & \\
\hline 389079 (C) & 8 & $\mathrm{~F}$ & 1960 & 5 & Ptosis & $\mathbf{S}$ & + & - & - & - & - & 9 & II & \\
\hline 303161 (B) & 9 & $\mathrm{~F}$ & 1946 & 5 & $\begin{array}{l}\text { Ptosis. } \\
\text { Diplopia. } \\
\text { Bulbar } \\
\text { weakness }\end{array}$ & SP & + & + & + & + & 6 & d. at 7 & - & \\
\hline
\end{tabular}


APPENDIX 1-continued

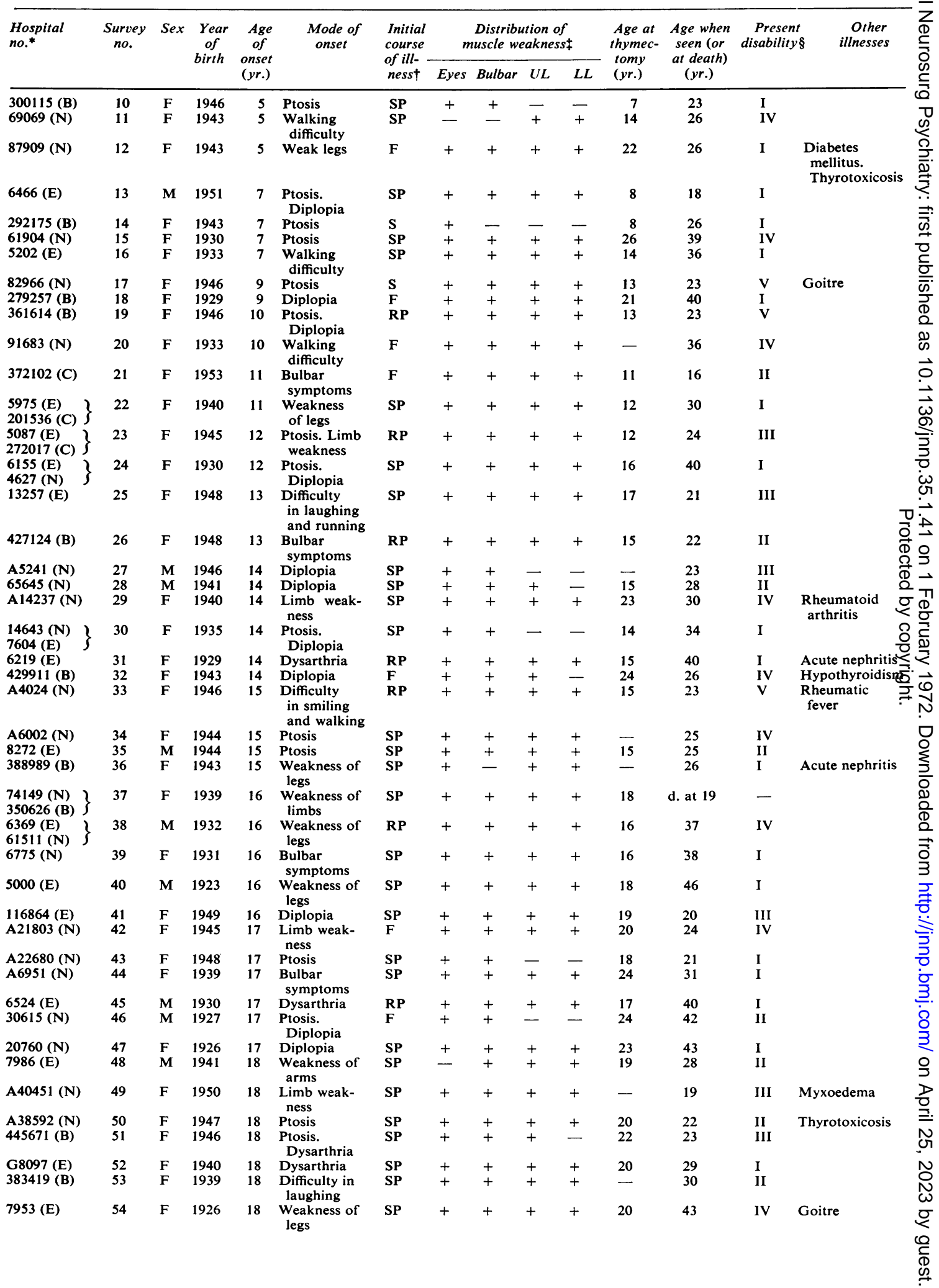


APPENDIX 1-continued

\begin{tabular}{|c|c|c|c|c|c|c|c|c|c|c|c|c|c|c|}
\hline \multirow[t]{2}{*}{$\begin{array}{l}\text { Hospital } \\
\text { no.* }\end{array}$} & \multirow[t]{2}{*}{$\begin{array}{l}\text { Survey } \\
\text { no. }\end{array}$} & \multirow[t]{2}{*}{ Sex } & \multirow{2}{*}{$\begin{array}{l}\text { Year } \\
\text { of } \\
\text { birth }\end{array}$} & \multirow{2}{*}{$\begin{array}{l}\text { Age } \\
\text { of } \\
\text { onset } \\
(y r .)\end{array}$} & \multirow[t]{2}{*}{$\begin{array}{c}\text { Mode of } \\
\text { onset }\end{array}$} & \multirow{2}{*}{$\begin{array}{l}\text { Initial } \\
\text { course } \\
\text { of ill- } \\
\text { ness }\end{array}$} & \multicolumn{4}{|c|}{$\begin{array}{c}\text { Distribution of } \\
\text { muscle weakness }\end{array}$} & \multirow{2}{*}{$\begin{array}{c}\text { Age at } \\
\text { thymec- } \\
- \text { tomy } \\
(y r .)\end{array}$} & \multirow{2}{*}{$\begin{array}{c}\text { Age when } \\
\text { seen }(\text { or } \\
\text { at death) } \\
(y r .)\end{array}$} & \multirow[t]{2}{*}{$\begin{array}{c}\text { Present } \\
\text { disability§ }\end{array}$} & \multirow[t]{2}{*}{$\begin{array}{c}\text { Other } \\
\text { illnesses }\end{array}$} \\
\hline & & & & & & & Eyes & Bulbar & $U L$ & $L L$ & & & & \\
\hline 15597 (E) & 55 & $\mathbf{M}$ & 1947 & 19 & Diplopia & SP & + & - & + & + & 20 & 22 & III & \\
\hline$A 10451$ (N) & 56 & $\mathbf{F}$ & 1942 & 19 & Diplopia & SP & + & + & + & + & 21 & 27 & II & \\
\hline A15967 (N) & 57 & $F$ & 1940 & 19 & $\begin{array}{l}\text { Ptosis. } \\
\text { Dysarthria }\end{array}$ & $\mathbf{S P}$ & + & + & + & + & 23 & abroad & I & \\
\hline $42883(N)$ & 58 & $\mathbf{F}$ & 1931 & 19 & $\begin{array}{l}\text { Limb weak- } \\
\text { ness }\end{array}$ & $\mathbf{S P}$ & + & + & + & + & 22 & 39 & III & \\
\hline
\end{tabular}

SECONDARY CASES OF MYASTHENIA GRAVIS: CLINICAL INFORMATION

\begin{tabular}{|c|c|c|c|c|c|c|c|c|c|c|c|c|c|}
\hline \multirow{2}{*}{$\begin{array}{l}\text { Relationship } \\
\text { to index } \\
\text { patient }\end{array}$} & \multirow[t]{2}{*}{$\begin{array}{l}\text { Hospital } \\
\text { no. }\end{array}$} & \multirow{2}{*}{$\begin{array}{c}\text { Year } \\
\text { of } \\
\text { birth }\end{array}$} & \multirow{2}{*}{$\begin{array}{l}\text { Age } \\
\text { at } \\
\text { onset } \\
(y r .)\end{array}$} & \multirow[t]{2}{*}{$\begin{array}{c}\text { Mode of } \\
\text { onset }\end{array}$} & \multirow{2}{*}{$\begin{array}{c}\text { Course } \\
\text { of } \\
\text { illness }\end{array}$} & \multicolumn{4}{|c|}{$\begin{array}{l}\text { Distribution of } \\
\text { muscle weakness }\end{array}$} & \multirow{2}{*}{$\begin{array}{c}\text { Age at } \\
\text { thymec- } \\
\quad \text { tomy } \\
(y r .)\end{array}$} & \multirow{2}{*}{$\begin{array}{c}\text { Age when } \\
\text { seen } \\
(y r .)\end{array}$} & \multirow[t]{2}{*}{$\begin{array}{l}\text { Present } \\
\text { disability }\end{array}$} & \multirow[t]{2}{*}{$\begin{array}{l}\text { Other } \\
\text { illnesses }\end{array}$} \\
\hline & & & & & & Eyes & Bulbar & $U L$ & $L L$ & & & & \\
\hline Brother of 4 & $418582(C)$ & 1960 & $6 / 12$ & $\begin{array}{l}\text { Ptosis. Diffi- } \\
\text { culty in } \\
\text { feeding }\end{array}$ & SP & + & + & - & - & 一 & 9 & II & \\
\hline Son of 20 & $1676(S)$ & 1957 & 4 & Dysarthria & SP & + & + & + & + & - & 12 & II & \\
\hline Sister of 51 & 471688 (B) & 1943 & 24 & Diplopia & SP & + & + & + & + & 一 & 26 & II & \\
\hline
\end{tabular}

* $N=$ The National Hospital $; E=$ New End; $B=S t$. Bartholomew's; $C=$ Hospital for Sick Children; $S=$ Southampton.

$+\mathrm{F}=$ Fluctuating, with remissions of six months or more; $\mathbf{S P}=\mathrm{Slowly}$ progressive; $\mathbf{R} \mathbf{P}=\mathbf{R}$ apidly progressive; $\mathbf{S}=\mathrm{Static}$ for two years or more at onset.

$\ddagger$ This applies to weakness at the time when the myasthenic illness was at its worst.

$\S I=$ No cholinergic drugs; II = no symptoms, on drugs; III = Mild symptoms, on drugs; IV=Moderately severe symptoms but still at work; $\mathrm{V}=$ Severely restricted life.

APPENDIX 2

GENETIC DATA OF EARLY-ONSET CASES OF MYASTHENIA GRAVIS

\begin{tabular}{|c|c|c|c|c|c|c|c|c|}
\hline Number in & & & Sibship & & & Mother & Father & Comments \\
\hline $\begin{array}{l}1 \\
2 \\
3 \\
4 \\
5\end{array}$ & $\begin{array}{l}\text { M ?/25 d. } 1956 \\
M 12 / 56^{*} \\
\text { F } 8 / 62 \\
M 7 / 60 \\
F 5 / 60^{*}\end{array}$ & $\begin{array}{l}\text { M } 6 / 27 \\
\text { M } 1 / 64 \\
M 4 / 64^{*} \\
M 1 / 62\end{array}$ & $\begin{array}{l}\text { M 4/29 } \\
F 1 / 66^{*}\end{array}$ & M 7/34 & $F 5 / 38^{*}$ & $\begin{array}{r}10 / 07 \\
3 / 36 \\
7 / 43 \\
2 / 35 \\
7 / 38\end{array}$ & $\begin{array}{r}7 / 01 \\
9 / 32 \\
11 / 40 \\
4 / 38 \\
10 / 35\end{array}$ & Parents are 1 st cousins \\
\hline
\end{tabular}

$\mathbf{M}=$ male, $\mathbf{F}=$ female, Index patients are asterisked, affected individuals are italicized, dates of birth are shown. 